\title{
Limonium hyblaeum (Plumbaginaceae), a cushion plant invading coastal southern Australia
}

\author{
R.F. Parsons \\ Department of Botany, La Trobe University, Bundoora, VIC 3086, AUSTRALIA \\ Email: r.parsons@latrobe.edu.au
}

\begin{abstract}
The Sicilian endemic herbaceous perennial plant Limonium hyblaeum (family Plumbaginaceae) is rapidly becoming a serious weed in South Australia and Victoria, where it invades saltmarshes and rocky coastal sites exposed to salt spray. It has small, light seeds that float and remain viable in sea water and which can also be dispersed readily by wind, animals and vehicles. It can form dense, extensive mats and buds sprouting from rhizomes allow encroachment into dense native vegetation. It seems certain to be apomictic and is readily able to become dominant.

Forming dense, compact cushions which accumulate large amounts of fibrous peat, Limonium hyblaeum is the first cushion plant to become naturalized in Australia; the importance of the cushion habit as an adaptation to salt spray is under-appreciated.
\end{abstract}

Some control measures for Limonium hyblaeum have begun in Victoria, but much remains to be done there and in the other southern Australian states; a ban on the sale of the species by nurseries is urgently required.

Cunninghamia (2013) 13: 267-274

doi: 10.7751cunninghamia.2013.004

\section{Introduction}

The Sicilian endemic herbaceous perennial plant Limonium hyblaeum Brullo (Sicilian Sea Lavender) (family Plumbaginaceae) is naturalized in Western Australia, South Australia and Victoria (AVH 2013). Erben (1986) was first to apply the name Limonium hyblaeum to Australian specimens. At the same time he recorded it from England, where it is still present (Online Atlas of the British and Irish Flora (OABIF) 2013) and from Chile (a single specimen). The first Australian flora account to recognize it under that name is Walsh (1996).
The first published record of its weedy behaviour in Australia is that by Adair et al. (2008) where it appears in a Victorian list of 'Lower Risk Weeds'. Since then, in Victoria there has been increasing awareness of two major infestations leading to the collapse of native plant communities and giving rise to the view that Limonium hyblaeum, with Lophopyrum ponticum (Podp.) A. Love and Spartina anglica C.E. Hubb. are the three most important weed threats to Victorian saltmarshes (Adair 2012). The aims of the present paper are to briefly review what is known of the biology of Limonium hyblaeum, the history of its spread in Australia, and of its effects on native plant communities. Limonium hyblaeum is the only Sicilian endemic and the only cushion plant to become naturalized in Australia. 


\section{The Species}

Limonium (family Plumbaginaceae) is a cosmopolitan genus with about 350 species (Kubitzki 1993), most of which are herbaceous perennials from coastal or inland saline, gypseous or alkaline soils (http://en.wikipedia.org/ wiki/Limonium; seen 21 Jan 2013). The genus is often taxonomically difficult; apomixis is very common, so that many species are microspecies occupying extremely limited areas (Cowan et al. 1998). The centre of diversity of the genus is the Mediterranean region (Cowan et al. 1998).

Limonium hyblaeum was described by Brullo (1980), having previously been lumped with other species. It is endemic to Sicily, where it is a species of rocky coasts with a very localized distribution (Brullo \& Pavone 1981). It is a putatively apomictic tetraploid; if apomictic, then a new population can be founded by a single individual (Cowan et al. 1998).

Limonium hyblaeum plants are herbaceous perennials to $25 \mathrm{~cm}$ high. As in many Limonium species, individual plants of Limonium hyblaeum have a shoot system usually made up of numerous small rosettes forming a dense cluster which can often become a hemispherical cushion (Figs. 1 and 2) or extensive mat by production of new rosettes. In addition, new rosettes are often produced along rhizomes, especially at the edges of patches of plants. These rosettes become new plants if the rhizome breaks for any reason (Rodrigo et al. 2012).

A similar but better-understood rhizomatous Limonium is Limonium vulgare Mill. whose individual plants can form clones up to $4 \mathrm{~m}$ across and rhizomes can extend for $60 \mathrm{~cm}$ per year allowing the species to occupy hundreds of hectares as a near-monoculture. Its lifespan is up to $30 \mathrm{yr}$ (Zadoks 2005). For Limonium vulgare and Limonium humile Mill. it is clear that reproduction by seed is only important when a new area is being invaded. Subsequent reproduction is largely by vegetative spread (Boorman 1968). The same seems to be true for Limonium hyblaeum (Rodrigo et al. 2012).

Limonium hyblaeum has small seeds $2 \mathrm{~mm}$ long (Walsh 1996). The fruit is a dry, membranous, one-seeded achene (Kubitzki 1993). In the genus and in Limonium hyblaeum itself, it is assumed that single seeds and the fruits are light enough to be readily dispersed both by wind and by animals (including birds, humans and rabbits), as well as by vehicles (Kubitzki 1993, Adair 2012, Rodrigo et al. 2012). On the south coast of England, it is assumed to be dispersed by gulls (OABIF 2013).

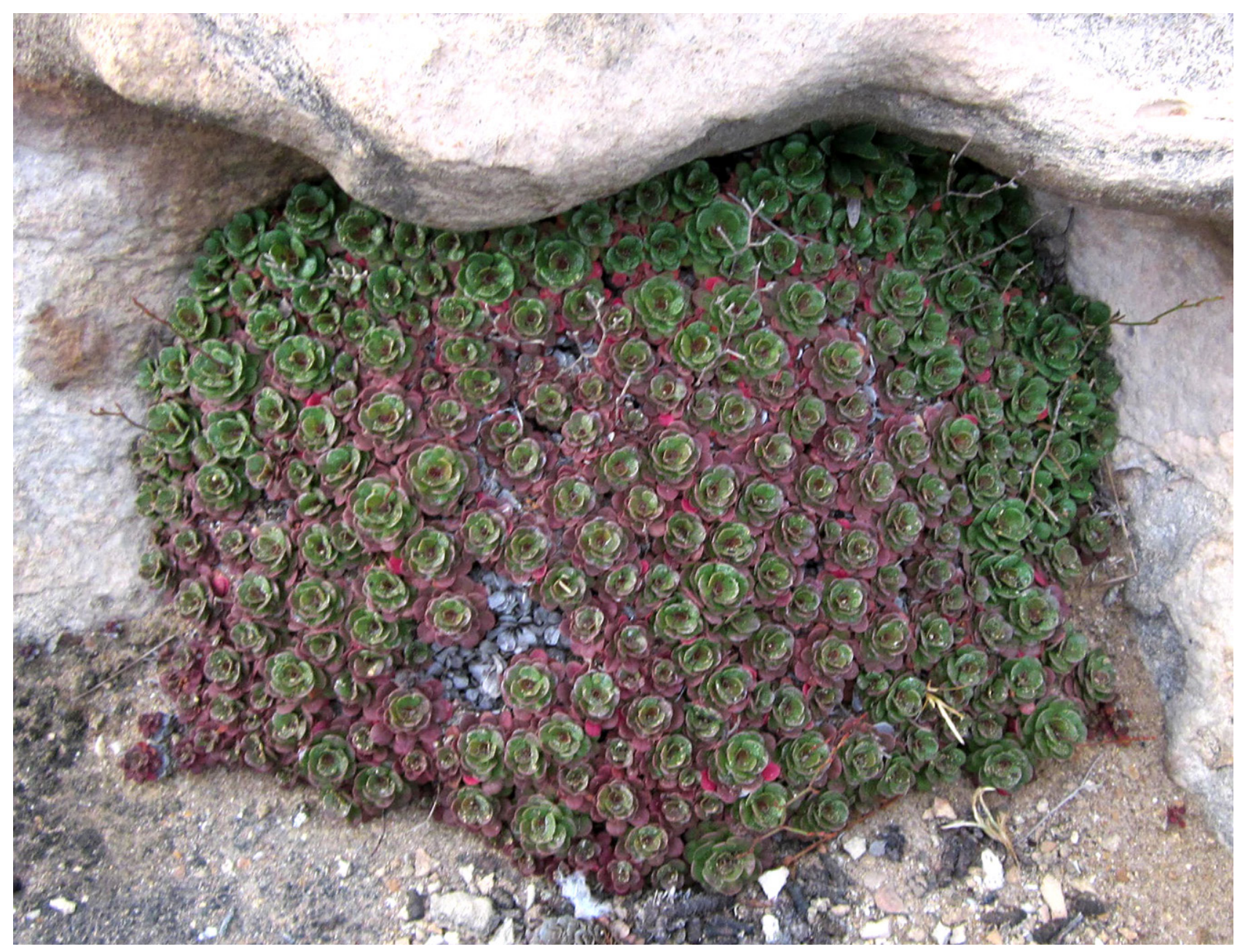

Fig. 1. Cushion of Limonium hyblaeum $20 \mathrm{~cm}$ wide showing dense canopy and numerous small rosettes. On calcarenite, Robe, South Australia (photo R.J. Bates). 
Limonium humile and Limonium vulgare seeds can float and survive long periods in sea water and the presence of germinating seeds in drift line debris shows that dispersal in sea water is important in colonizing new areas (Boorman 1968). Field observations suggest that the same is very likely to be true for Limonium hyblaeum (Rodrigo et al. 2012).

Like other species of Limonium examined, Limonium hyblaeum has salt-secreting glands on its leaves and stems, which can secrete a range of ions taken up from the soil solution, including sodium and chloride (Faraday \& Thomson 1986).

\section{The habitat}

Records of Limonium hyblaeum from Sicily and England are from rocky coastal sites exposed to salt spray (Brullo 1980, OABIF 2013), as are many of the Australian ones (Adair 2012, herbarium specimen labels at AD-Adelaide) but it is now clear that in Victoria it can survive periodic tidal inundation and can invade and suppress native coastal salt marsh vegetation (Adair 2012, Rodrigo et al. 2012).

Of the rocky coastal sites, many in South Australia are on limestone (Fig. 1), as are all those in England (specimen labels at AD, OABIF 2013), while many in Victoria are

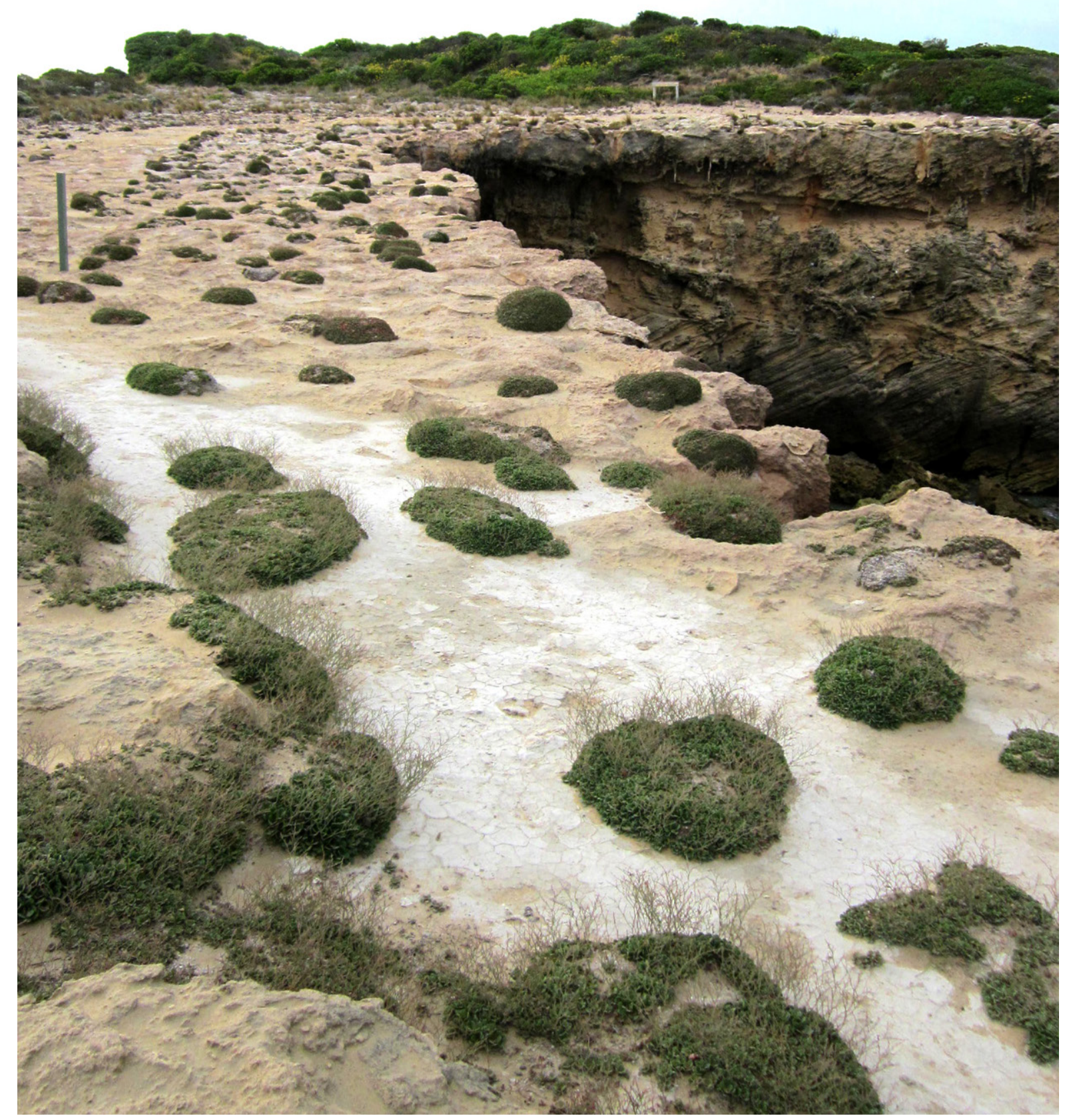

Fig. 2. Cushions of Limonium hyblaeum on coastal calcarenite clifftop, Robe, South Australia (photo R.J. Bates). 
on basalt (Adair 2012) suggesting some connection with reasonably high soil pH (Adair 2012) or calcium status.

Nearly all records are from coastal sites with elevated $\mathrm{NaCl}$ levels from salt spray or tides. However, three specimens at $\mathrm{AD}$ are from inland sites. The roadside gravel record (Brodie 3174) looks likely to be non-saline, as do some of the occurrences listed in Adair (2012).

\section{History of invasion in Australia}

\section{South Australia}

The earliest record of a naturalized specimen in Australia is from Port Adelaide in 1889 (Toelken 1987). From 1889 to 1959 there are nine collections from suburban Adelaide and a 1932 one from Eyre Peninsula near Port Lincoln (specimens held at AD). Wider spread followed: Yorke Peninsula (by 1966), Victor Harbour (by 1973), the South East (by 1982), and Kangaroo Island (by 1987). Spread continues in all these regions.

The western limit for the AD specimens is Baird Bay near Streaky Bay (Brodie no. 1981) but in 2012 it was seen well to the west at Fowlers Bay, but not at the Nullarbor Plain cliff top lookouts further west in South Australia (J. Eichler pers. comm..).

\section{Victoria}

The five Victorian collections are all coastal; four, including the oldest (1984), are from an extensive stand at Port Fairy that must have originated years earlier (AVH 2013, N.G. Walsh pers. comm.). The other collection is a 2004 one from the Cheetham Salt Works at Point Henry near Geelong (AVH
2013) which is from the only other extensive Victorian stand (Adair 2012). There are six small patches scattered between the two, two of which have now been deliberately eliminated (Adair 2012).

\section{New South Wales}

The single AVH (2013) record is from 2003 from a very localized patch near Lake Cargelligo in central NSW (noncoastal), but a coastal record made in 2011 from saltmarsh on Saratoga Island near Gosford (specimen at UNSW: N. Rea 9522) needs further investigating in case it is not yet too late to eradicate the species there.

\section{Western Australia}

The six Western Australian records are all coastal (Fig, 3), with three from suburban Perth, the earliest in 1973. The other three are from two different areas up to $400 \mathrm{~km} \mathrm{~N}$ of Perth (dates 1981-2003). (AVH 2013).

\section{The major infestations}

For Victoria, Adair's (2012) overview clearly shows two major infestations. Firstly, around Port Fairy, it is dense and concentrated for about $5 \mathrm{~km}$ of coastline (Adair 2012) and completely encircles the outer edge of the closely adjacent Griffiths Island in a band up to $4 \mathrm{~m}$ wide with $100 \%$ cover in places. Much of this involves invasion of salt marsh (Rodrigo et al. 2012). For good images of this infestation, see Carr (2012). Secondly, at Cheetham Salt Works, Point Henry, near Geelong, the infestation size was $30 \mathrm{~m}^{2}$ in 2010 , but became 1.5 ha in 2011, a 500-fold increase (Adair 2012). I assume from the images in Adair (2012) that at least part of this site is on well-drained sandy or shelly rises.

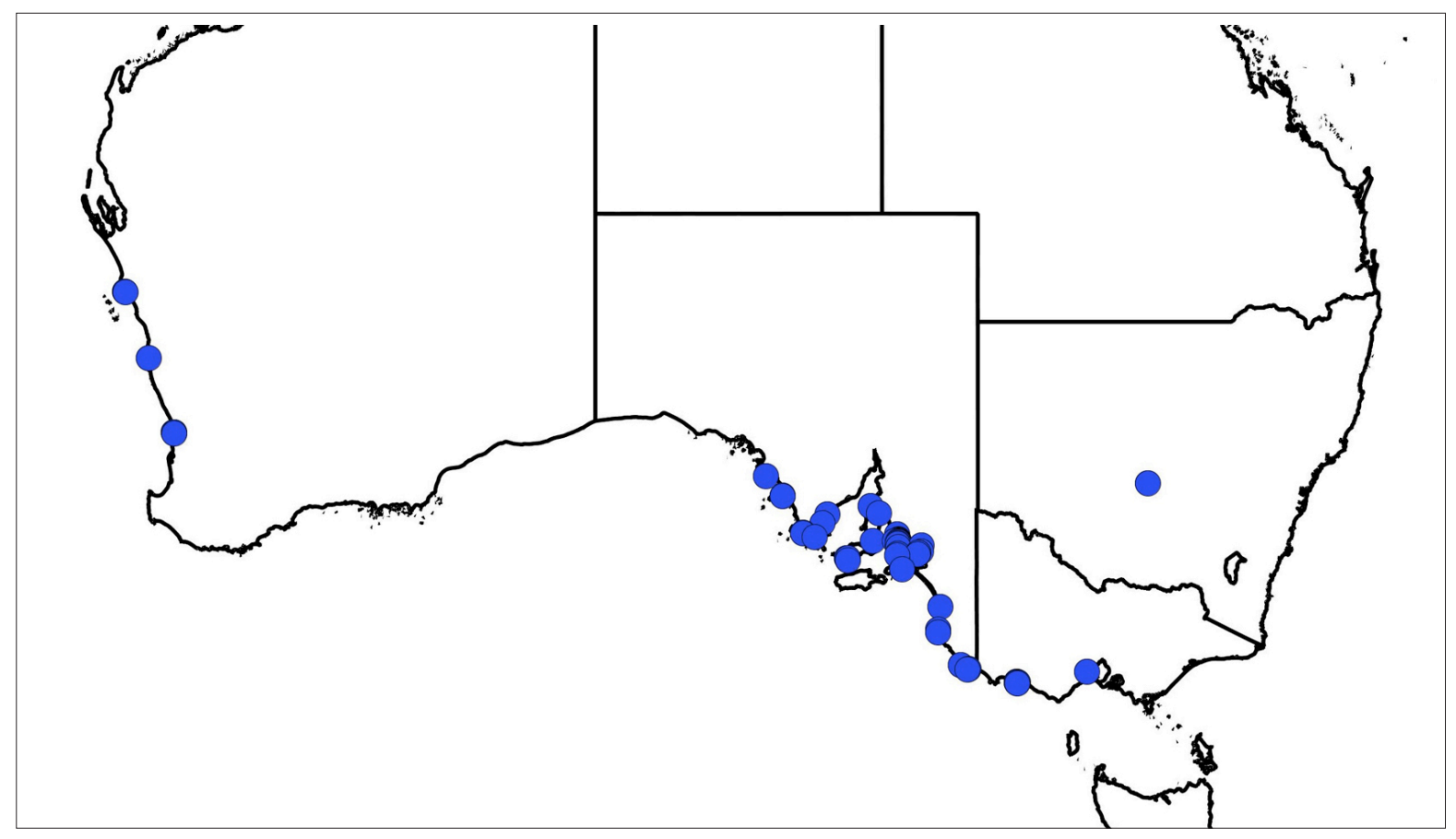

Fig. 3. Distribution of Limonium hyblaeum in Australia (AVH 2013). A recent record for coastal NSW is dealt with in the text. 
There have been no systematic surveys for Limonium hyblaeum in South Australia, Western Australia or New South Wales. In South Australia, notes on herbarium specimens at $\mathrm{AD}$ suggest serious problems at a minimum of three sites: a) Robe 2009 'forms a thick monoculture.... very, very common.' Brodie 796. b) Port Elliot 2006 'absolutely thick' and excluding native flora. Murfet 5147. c) Elliston 2010 'dense stands... found along road for many miles coming into town.' Brodie 1972. All three stands involve rocky coastal sites.

\section{Mode of introduction}

Limonium hyblaeum is on sale at a few specialist nurseries in Australia and is grown for cut flowers and as an ornamental garden plant. The Port Fairy infestation reportedly started with a garden escape (Adair 2012) and in the coastal South Australian town of Marino, Limonium hyblaeum (locally called Statice) has spread from a garden planting, down a road verge and into a Conservation Park (specimen labels at AD; E.L. Robertson 242, 496).

Another South Australian Limonium hyblaeum collection at AD (from Coffin Bay) is annotated 'Introduced with other Limonium spp. to help combat soil salinity.' (C.R.Alcock 6687; 1979. Alcock was a government weeds officer). Further data are badly needed to see if this practice still occurs in any area; deliberate introduction of salt-tolerant species for agriculture and salt-land remediation has lead to other weed problems, such as the cases of Bassia scoparia (L.) A.J. Scott and Puccinellia ciliata Bor (Boon et al. 2011).

Ease of dispersal for Limonium hyblaeum by animals, wind and water is noted above. The means by which the species reached Australia, Chile and England from Sicily (Erben 1986) are unknown; introductions as a garden plant are perhaps the most likely.

\section{Current control actions}

The Victorian Department of Sustainability and Environment (DSE) helped to organize workshops on the Limonium hyblaeum weed problem at Geelong Botanic Gardens on 31 May 2012 and Phillip Island on 12 September 2012. Successful elimination of two small populations by handpulling was described, as were effective herbicide treatments (Adair 2012). Another result was subsequent DSE public communications describing the species, urging vigilance in uninvaded areas, stressing the importance of early detection and giving instructions if found (e.g. South Gippsland Landcare Network 2012).

I have not been able to find a reference to any control actions at all in other states.

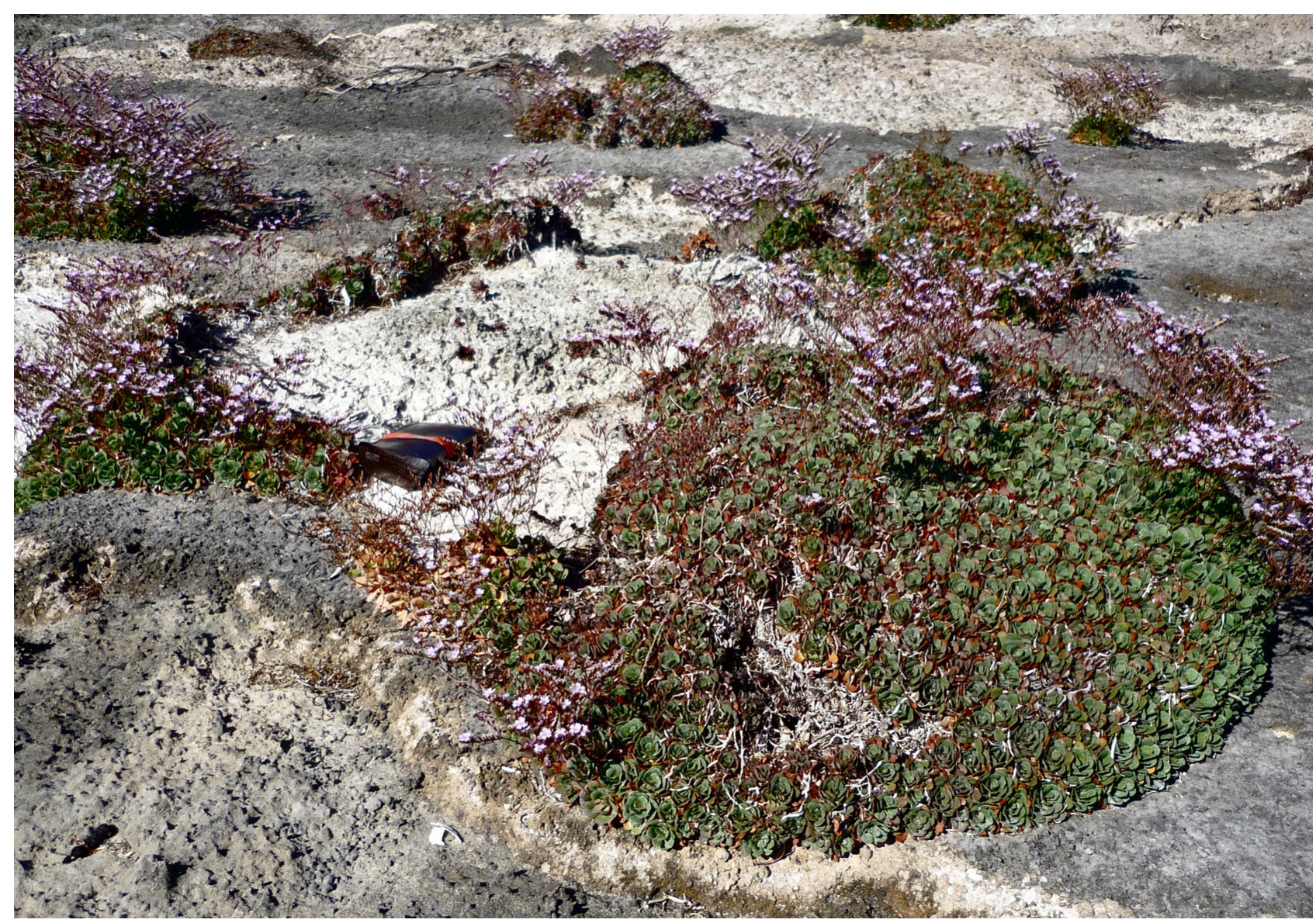

Fig. 4. Degenerating cushion of Limonium hyblaeum $40 \mathrm{~cm}$ wide. Mounds of light grey to white fibrous peat can be seen in left part of cushion and sitting on grey calcarenite in background. Coffin Bay, South Australia (photo A.N. Parsons). 


\section{Limonium and the cushion habit}

Cushion plants are defined as chamaephytes and hemicryptophytes that, growing singly, take on a hemispherical or subhemispherical shape due to the close branching of their shoots and their short internodes (Parsons \& Gibson 2009), resulting in a smooth, dense, uniform shoot surface. At least 60 taxa occur in lowland southern Australia (Parsons \& Gibson 2009).

There are several genera in the Plumbaginaceae in which species are commonly pulvinate (i.e. cushion-like) (Kubitzki 1993) including alpine cushion plants like Armeria caespitosa (Gomez Ortega) Boiss. in DC (Garcia-Camacho et al. 2012). In Sicily and the surrounding islands, at least three species of Limonium, including Limonium hyblaeum (Figure1), commonly occur as cushion plants (Brullo 1980). The occurrence of Limonium hyblaeum in Australia constitutes the first time a cushion plant has naturalized here.

For Limonium hyblaeum, like most lowland cushion plants, it is common to find plants both in cushion and noncushion form (see Parsons \& Gibson 2009). The cushions are compact and accumulate large amounts of fibrous peat within the cushion (Fig. 4) like some other cushion species (Parsons \& Gibson 2009). The large amounts of peat might imply considerable plant longevity, as suggested on different grounds for some other Limonium species (Boorman 1968).

In stands of Limonium hyblaeum, it is common to find old plants which are gradually dying back, with a progressively widening gap in the middle of the shrub, leaving a ring of living shoots around the perimeter (Fig. 5). This is identical to the degenerate phase of growth described by Watt (1955) for Calluna and other shrubs.

The association of the cushion habit with the salt spray zone of exposed coasts has been pointed out for some species, both in the Mediterranean (Nimis 1981) and in southern Australia (Parsons \& Gibson 2009). The smooth, uniform surface of the cushion and its shape minimize the amount of salt spray intercepted; any shoot that extends beyond the common smooth surface will be exposed to a higher load of salt spray. The only reference I know dealing with this in Limonium is Schweingruber et al. (2006) for Limonium caprariense (Font Quer \& Marcos) Pignatti, but the general phenomenon is dealt with by Boyce (1954). In the genus Limonium, clearly the cushion habit is more likely to be found in species which can occur in the salt spray zone than in species like Limonium vulgare which occur only in saltmarshes.

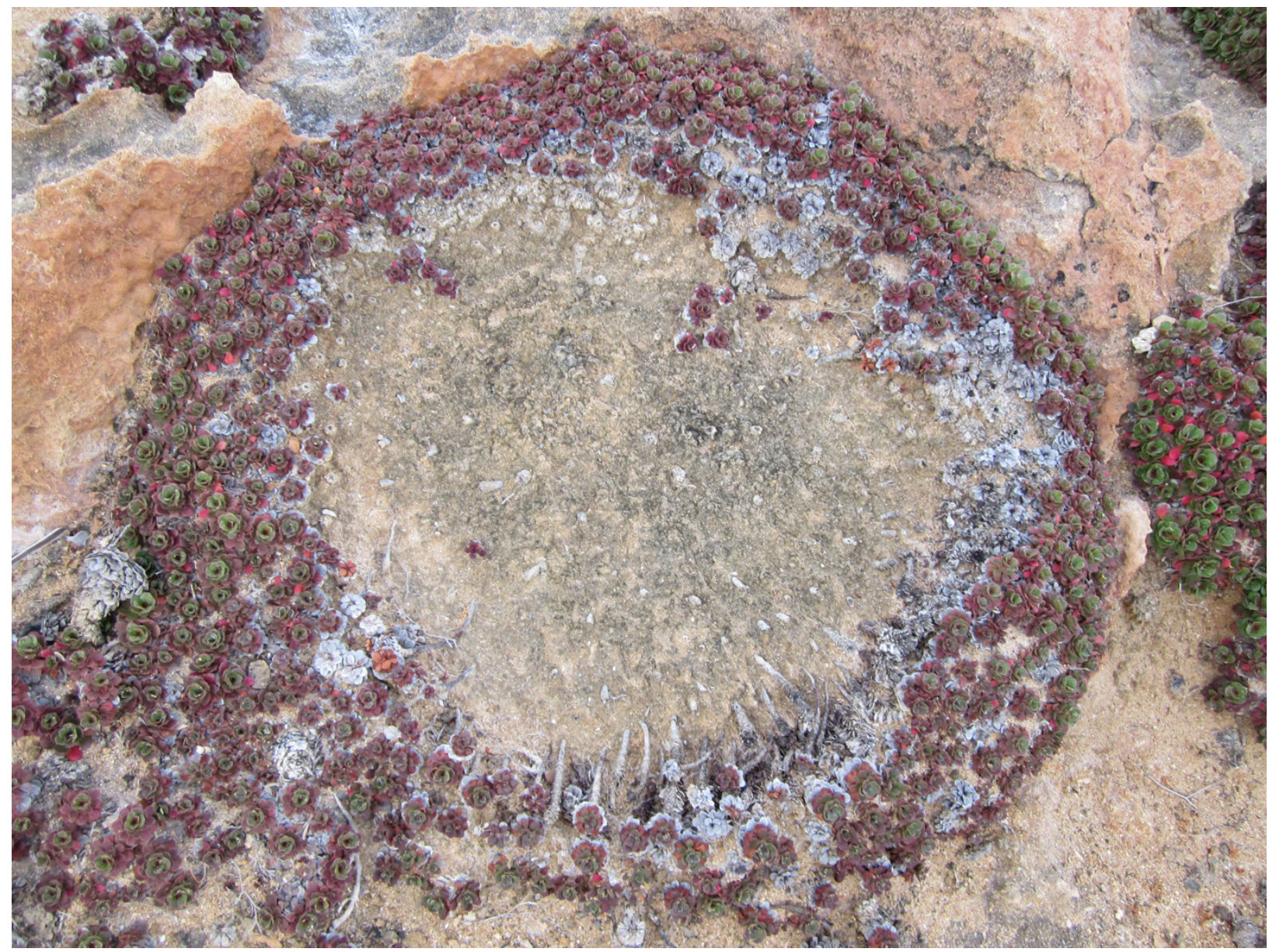

Fig. 5. Degenerating cushion of Limonium hyblaeum $25 \mathrm{~cm}$ wide with progressively widening gap in centre. This is filled with light grey fibrous peat. On calcarenite, Robe, South Australia (photo R.J. Bates). 


\section{Concluding discussion}

Being a cushion plant endemic to Sicily, Limonium hyblaeum is an unusual weed in the Australian context. However, in terms of traits important for weediness (Pheloung et al. 1999), it is clear why it is becoming so successful. The seeds have high dispersability in sea water and by wind, animals and vehicles. It seems certain to be apomictic. It can form extensive mats; also buds sprouting from rhizomes allow encroachment into dense vegetation (Rodrigo et al. 2012). It is readily able to become dominant.

Both in the salt spray zone of rocky coastlines and in saltmarshes, it is clearly a rapidly emerging weed, serious enough to be a major ecosystem transformer. While some control measures have begun in Victoria, much remains to be done both there and especially in New South Wales where Coastal Saltmarsh is listed as an Endangered Ecological Community (NSW threatened Species Conservation Act) as well as in South Australia and Western Australia. A ban on the sale of the species by nurseries should be implemented immediately.

In 2010, Subtropical and Temperate Coastal Saltmarsh was nominated as threatened Australia-wide under the EPBC Act. Consequently, the relevant Draft Conservation Advice document was released for public comment in January 2013 (http://www.environment.gov.au/biodiversity/threatened/ communities/-temperate-coastal-saltmarsh.html). The section on threats lists a number of invasive and potentially invasive species but not Limonium hyblaeum. This species clearly needs to be taken into account in the on-going assessment process.

There are possible threats from other alien Limonium species, 37 species of which are recorded as naturalized in Australia. Five species including Limonium hyblaeum have been recorded as weeds here (Randall 2007). Though none are treated as invasive, that is clearly now the case for Limonium hyblaeum. Limonium perezii (Stapf) Hubb. is both naturalized here and very widely promoted and sold in our nursery trade (e.g. Australian Broadcasting Commission 2011), is highly invasive in California (Weedwatch 2013) and clearly should be removed from sale here as quickly as possible.

\section{Acknowledgements}

It is a pleasure to thank Dr Robin Adair, Rob Bates, David Cameron, Sandy Lloyd, Rosemary Taplin and Neville Walsh.

\section{References}

Adair, R. (2012) www.australisbiological.com.au/Limoniumpresentation-Phillip-Island-12-September-2012.pdf

Adair, R., Cheal, D. \& White, M. (2008) Advisory list of environmental weeds in coastal plains and heathy forest bioregions of Victoria. http://www.dse.vic.gov.au/weeds

Australian Broadcasting Commission (2011) Gardening Australia - Plant Profile Limonium. http://www.abc.net.au/gardening/ stories/s1866714.htm

AVH 2013. Australia's Virtual Herbarium. http://www.avh.ala.org. $\mathrm{au}$

Boon, P.I., Allen, T. \& Brook, J. (2011) Mangroves and Coastal Saltmarsh of Victoria. OzCoasts: Canberra.

Boorman, L.A. (1968) Some aspects of the reproductive biology of Limonium vulgare Mill. and Limonium humile Mill. Annals of Botany 32: 803-824.

Boyce, S.G. (1954) The salt spray community. Ecological Monographs 24: 29-67.

Brullo, S. (1980) Taxonomic and nomenclatural notes on the genus Limonium in Sicily. Botaniska Notiser 133: 281-293.

Brullo, S. \& Pavone, P. (1981) Chromosome numbers in the Sicilian species of Limonium Miller. Anales Jardin Botanico Madrid 37: 535-555.

Carr, G. (2012) Overview of coastal saltmarsh and mangrove vegetation in Victoria . In Sainty, G. (Ed.) Estuary Plants and What's Happening to them in South-east Australia pp. 277 297. Sainty Books: Sydney.

Cowan, R., Ingrouille, M.J. \& Lledo, M.D. (1998) The taxonomic treatment of agamosperms in the genus Limonium Mill. (Plumbaginaceae). Folia Geobotanica 33: 353-366.

Erben, M. (1986) Bemerkungen zur taxonomie der gattung Limonium. Mitteilungen Botanischen Munchen 22: 203-220.

Faraday, C.D. \& Thomson, W.W. (1986) Functional aspects of the salt glands of the Plumbaginaceae. Journal of Experimental Botany 37: 1129-1135.

Garcia-Camacho, R., Albert, M.J. \& Escudero, A. (2012) Smallscale demographic compensation in a high-mountain endemic: the low edge stands still. Plant Ecology \& Diversity 5: 37-44.

Kubitzki, K. (1993) Plumbaginaceae. In Kubitzki, K. (Ed.) The Families and Genera of Vascular Plants, vol. 2, pp. 523-530. Springer: Berlin.

Online Atlas of the British \& Irish Flora (2013) http://www.brc. ac.uk/plantatlas/index.php?q=plant/limonium hyblaeum (seen on 25 Jan 2013).

Parsons, R.F. \& Gibson, N. (2009) The cushion plants of lowland southern Australia. Cunninghamia 11: 177-184.

Pheloung, P.C. Williams, P.A. \& Halloy, S.R. (1999) A weed risk assessment model for use as a biosecurity tool evaluating plant introductions. Journal of Environmental Management 57: 239251.

Randall, R. (2002) A Global Compendium of Weeds. R.G. \& F.J. Richardson: Meredith, Victoria.

Randall, R.P. (2007) The Introduced Flora of Australia and its Weed Status. CRC Weed Management: Adelaide. 
Rodrigo, T.M, Gibson, M., Versace, V.L. \& Carr, G.W. (2012) Report on the biology and ecology of Limonium hyblaeum Brullo at Port Fairy, Victoria with respect to its invasive potential. Deakin University unpubl. rept. Contact maryg@deakin.edu.au. https://www.researchgate.net/publication/236662021_Report_ on_the_biology_and_ecology_of_Limonium_hyblaeum Brullo_at_Port_Fairy_Victoria_with_respect_to_its_invasive_ potential?ev=srch_pub

Schweingruber, F.H., Borner, A. \& Schulze, E.-D. (2006) Atlas of Woody Plant Stems. Springer: Berlin.

South Gippsland Landcare Network (2012) Weed Talk: A lavender that isn't so pretty. http://www.southgippslandweeds.com.au/ weedtalk

Toelken, H.R. (1987) Limonium hyblaeum: an early introduction to Australia named at last. Australian Systematic Botany Society Newsletter No. 52: 14.

Walsh, N.G. (1996) Plumbaginaceae. In Walsh, N.G. \& Entwisle, T.J. (Eds.) Flora of Victoria vol. 3, pp. 296-299. Inkata: Melbourne.

Watt, A.S. (1955) Bracken versus heather, a study in plant sociology. Journal of Ecology 43: 490-506.

Weedwatch (2013) weedwatch.lasgrwc.org/docs/matrix/ Limonium_perezii_042907.pdf.

Zadoks, J.C. (2005) Sea lavender, rust and mildew. Wageningen Academic Publishers:Wageningen.

Manuscript accepted 8 May 2013 